\title{
PENGETAHUAN DAN UPAYA KONSERVASI KAYU SOWANG (Xanthostemon sp.) MASYARAKAT KAMPUNG DOYO LAMA DAN KAMPUNG HARAPAN PADA KAWASAN CAGAR ALAM PEGUNUNGAN CYCLOOP
}

\author{
Leonardo Elisa Aisoi \\ Program Studi Pendidikan Biologi Universitas Cenderawasih; leon_aisoi@yahoo.com
}

\begin{abstract}
This research was conducted to determine the knowledge and conservation efforts of the people of Doyo Lama villageand Harapanvillage. The research was carried out for three months, namely, from July to September 2020, using the observation method; interview method; documentation method; and literature study methods, and analyzed descriptively qualitatively. The results showed that knowledge about sowang wood (Xanthostemon sp.), is a traditional knowledge passed down from generation to generation orally. The people of Doyo Lama village call sowang by the name toang (meaning hard and strong), and Harapan village named howan(meaning wood that is durable and not easily weathered). The people of Doyo Lamavillage know two species of sowang wood, namely broad-leaved species and small-leaved species. The people ofHarapan villagealso recognize two species, namely the red-flowered species and the yellow-flowered species. The broad-leaved species and the red-flowered species are Xanthostemonnovoguineensis species. While the species with small leaves and yellow flowers are Xanthostemonpapuanus. Traditional knowledge and use of sowang wood by the people of Doyo Lama villageand Harapanvillage is decreasing, influenced by the development of modern life, because until now there have been no efforts and conservation activities for sowang wood in the two villages and there has been a shift in cultural values from traditional be modern. While the species with small leaves and yellow flowers are Xanthostemonpapuanus. Traditional knowledge and use of sowang wood by the people of Doyo Lama villageand Harapanvillage is decreasing, influenced by the development of modern life, because until now there have been no efforts and conservation activities for sowang wood in the two villages and there has been a shift in cultural values from traditional be modern. While the species with small leaves and yellow flowers are Xanthostemonpapuanus. Traditional knowledge and use of sowang wood by the people of Doyo Lama villageand Harapan villageis decreasing, influenced by the development of modern life, because until now there have been no efforts and conservation activities for sowang wood in the two villages and there has been a shift in cultural values from traditional be modern.
\end{abstract}

Keywords: Knowledge; Conservation; Sowang; Cycloop

\begin{abstract}
ABSTRAK
Penelitian ini dilakukan untuk mengetahui pengetahuan dan upaya-upaya konservasi masyarakat Kampung Doyo Lama dan Kampung Harapan. Penelitian dilaksanakan selama tiga bulan yaitu, pada bulan Juli hingga bulan September 2020, dengan menggunakan metode observasi; metode wawancara; metode dokumentasi; dan metode studi kepustakaan, dan dianalisis secara deskriptif kualitatif. Hasil penelitian menunjukan bahwa pengetahuan tentang kayu sowang (Xanthostemon sp.), merupakan pengetahuan tradisional yang diwariskan dari generasi ke generasi secara lisan. Masyarakat Kampung Doyo Lama menyebut sowang dengan nama toang (artinya keras dan kuat), dan Kampung Harapan
\end{abstract}


menamakan howan(artinya kayu yang tahan lama dan tidak mudah lapuk). Masyarakat Kampung Doyo Lama mengenal dua spesies kayu sowang yaitu spesies berdaun lebar dan spesies berdaun kecil. Masyarakat Kampung Harapan juga mengenal dua spesies yaitu spesies berbunga merah dan spesies berbunga kuning. Spesies berdaun lebar dan spesies berbunga merah merupakan spesies Xanthostemon novoguineensis. Sedangkan spesies berdaun kecil dan berbunga kuning yaitu Xanthostemon papuanus. Pengetahuan dan pemanfaatan kayu sowang secara tradisional oleh masyarakat Kampung Doyo Lama dan Harapan semakin berkurang, dipengaruhi oleh perkembangan kehidupan modern, karena sampai saat ini belum ada upaya dan kegiatan konservasi terhadap kayu sowang di kedua kampung tersebut dan telah terjadi pergeseran nilai-nilai budaya dari tradisonal menjadi modern.

Kata Kunci: Pengetahuan; Konservasi; Sowang; Cycloop.

\section{PENDAHULUAN}

Papua memiliki tingkat kekayaan spesies dan tingkat endemisitas yang sangat tinggi. Untuk tetap dapat melestarikan potensi sumber daya alam Papua, maka pemerintah telah menetapkan kawasankawasan tertentu sebagai kawasan konservasi sumber daya alam (Cannon J. C., 2020). Satu di antaranya adalah kawasan cagar alam. Kawasan cagar alam adalah kawasan suaka alam yang karena keadaan alamnya mempunyai kekhasan flora dan fauna serta ekosistem (Samedi, 2015). Kekhasan ini perlu dilindungi karena perkembangannya berlangsung secara alami. Kawasan cagar alam Pegunungan Cycloop, merupakan suatu gugusan pegunungan yang membentang dari sebelah timur kota Jayapura Papua, terletak membujur ke sebelah barat. Kawasan Pegunungan Cycloop ditetapkan sebagai kawasan konservasi dengan status cagar alam pada tahun 1978, berdasarkan Surat Keputusan Menteri Pertanian RI No:
56/Kpts/Um/10/I/1978, tanggal 18 November 1987 yang meliputi kawasan seluas 22.520 ha (WWF, 1991; Ap dkk., 2010).

Menurut WWF (1991) flora dan fauna yang ada di kawasan ini menunjukkan ciriciri endemisitas tersendiri dari wilayah lain di Papua tetapi juga mempunyai jenis-jenis tumbuhan tinggi yang merupakan tumbuhan asli Papua, seperti pohon kayu besi (Intsia sp), matoa (Pometia sp.) dan pohon kayu sowang (Xanthostemon sp.) tumbuhan ini memiliki potensi yang penting untuk menunjang aktivitas kehidupan sosial, budaya, dan ekonomi komunitas masyarakat di kawasan Pegunungan Cycloop.

Pohon kayu sowang telah lama dikenal dan dimanfaatkan oleh komunitas masyarakat Kampung Doyo Lama dan Kampung Harapan. Mereka memiliki sistem pengetahuan tertentu dalam memanfaatkan kayu sowang. Sistem pengetahuan tersebut terancam hilang dalam tatanan sosial budaya seiring dengan semakin menurunnya 
Jurnal Ilmu Pendidikan Indonesia 9 (2) : 93- 105 | 95

populasi kayu sowang di Kawasan Cagar Alam Pegunungan Cycloop.

Untuk dapat mengkonservasi kayu sowang, maka perlu adanya informasi yang lengkap dan benar mengenai pengetahuan dan upaya konservasi kayu sowang, oleh sebab itu tujuan penelitian ini adalah untuk mengetahui pengetahuan masyarakat Kampung Doyo Lama dan Kampung Harapan tentang kayu sowang dan untuk mengetahui upaya-upaya konservasi kayu sowang pada kawasan Cagar Alam Pegunungan Cycloop, dengan mempertimbangkan dinamika dan keperluan konservasi, maka dengan adanya penelitian ini akan membantu kita untuk mendapatkan informasi mengenai pengetahuan dan upaya konservasi kayu sowang pada masyarakat Kampung Doyo Lama dan Kampung Harapan pada Kawasan Cagar Alam Pegunungan Cycloop.

\section{METODE PENELITIAN}

\section{Bahan dan Alat Penelitian}

\section{a. Bahan Penelitian}

Tumbuhan (Xanthostemon sp.)

\section{b. Alat yang digunakan}

Alat-alat yang digunakan dalam penelitian ini adalah Tape recorder merek SONY mz.445, Alat tulis, Kamera digital merek Spectra MMF 330, Interview guide atau panduan pertanyaan, perlengkapan pembuatan spesimen herbarium tumbuhan (pisau, label, kertas koran, dan tali raffia)

\section{Tempat dan Waktu Penelitian}

Penelitian ini di lakukan di Masyarakat Kampung Doyo Baru Distrik Waibu dan Kampung Harapan Sentani Distrik Sentani Timur, Kabupaten Jayapura. Berlangsung selama tiga bulan, yaitu pada bulan Juli sampai dengan bulan September 2020.

\section{Populasi dan Sampel}

Populasi dalam penelitian ini adalah komunitas masyarakat Kampung Doyo Lama dan Kampung Harapan, dan sampel dalam penelitian ini adalah informan yang dipilih, dikategorikan menjadi tiga, yaitu informan pangkal, informan kunci, dan informan pelengkap.

\section{Metode Pengumpulan Data}

Metode pengumpulan data yang digunakan dalam penelitian adalah metode Observasi, dengan pengamatan secara langsung di lokasi penelitian yang bertujuan untuk mengetahui dan memperoleh data tentang obyek penelitian, metode Wawancara dilakukan dengan mengadakan dialog oleh pewawancara terhadap informan dan yang bertujuan memperoleh informasi dari masyarakat tentang obyek penelitian, metode Dokumentasi dengan melakukan pemotretan, pencatatan, dan pengambilan data lainnya terhadap kayu sowang, yang digunakan oleh masyarakat, sebagai data 
pelengkap, dan metode Studi Kepustakaan yaitu dengan pengumpulandata-data dengan menggunakan literatur yang berhubungan dengan penelitian ini.

\section{Analisa Data}

Data hasil pengamatan akan dianalisa secara deskriptif kualitatif, yang dimaksud dengan metode ini adalah metode yang digunakan untuk mendeskripsikan dan mengelompokkan kembali semua data yang diperoleh menurut hasil wawancara, data sekunder, data primer, dan dokumentasi lainnya berdasarkan kualitas data, kemudian dianalisa dirumuskan menjadi suatu kesimpulan.

\section{HASIL DAN PEMBAHASAN}

\section{Deskripsi Kayu Sowang}

Kayu sowang merupakan pohon yang tumbuh tegak, tinggi bebas cabang 10-25m, dengan diameter batang dewasa $20-80 \mathrm{~cm}$, percabangan tidak teratur dan tajuk melebar. Batang berbentuk selindris hingga agak gepeng dengan benjolan yang berlekuk dangkal hingga dalam. Kulit pohon coklat keputihan dengan bagian dalam berwarna coklat kemerahan (Tanjung, dkk. 2007; Wilujeng dan Simbiak, 2015). Kulit mati yang mengelupas berbentuk lempengan yang bergantungan secara vertikal dan memiliki tebal kulit 1-2cm. Bagian dalam batang (kayu gubal) berwarna merah, kayu keras berwarna kehitaman (Jamlean, 1998; Wilujeng dan Simbiak, 2015) Daun Xanthostemon sp. berbentuk bulat telur, hingga oval, permukaan atas licin, berwarna hijau, sedangkan permukaan bawah berwarna hijau pucat, tepi daun rata dengan ujung bulat berlekuk dan duduk berseling, panjang daun 8-15 cm, lebarnya $4-7 \mathrm{~cm}$. Bunganya menyerupai bunga jambu, kelopak berwarna hijau, mempunyai mahkota, benang sari dan putik. Bunga termasuk dalam kelompok bunga majemuk terbatas. Buah yang masih mudah berwarna hijau, dan yang telah tua berwarna coklat dan terbelah menjadi 3 dimana tiap ruangan terdapat sekat, yang dapat membagi buah menjadi 2 bagian, biji berukuran sedang dengan diameter $1-2,5 \mathrm{~cm}$, berbentuk pipih hingga bundar (Jamlean, 1998; Wilujeng dan Simbiak, 2015).

\section{Pengetahuan dan Pemanfaatan Kayu Sowang oleh Mayarakat Kampung Doyo Lama}

Pengetahuan dan pemanfaatan kayu sowang oleh masyarakat Kampung Doyo Lama. Masyarakat kampung Doyo Lama mengenal dua spesies kayu sowang. Masyarakat membedakan kayu sowang berdasarkan morfologi daun kayu sowang, yaitu spesies yang pertama adalah kayu sowang yang berdaun lebar (Xanthostemon novoguineensis) (gambar 1) dan yang kedua kayu sowang yang berdaun kecil 
Jurnal Ilmu Pendidikan Indonesia 9 (2) : 93- 105 | 97

(Xanthostemon papuanus) (gambar 2). Daun kayu sowang merupakan daun tidak lengkap karena hanya terdiri dari tangkai (petiolus) dan helaian daun (lamina). Panjang daun kayu sowang berdaun lebar, yaitu 10-14,5 $\mathrm{cm}$, dengan lebar 5-6,5 cm, sedangkan panjang daun kayu sowang berdaun kecil yaitu 6-10 cm dengan lebar 3-5 cm. Dengan mempelajari perbandingan benuk daun maka daun kayu sowang berdaun lebar dan kayu sowang berdaun kecil, kedua-duanya berbentuk daun jorong, yaitu daun yang perbandingan panjang dan lebar adalah 1,5 2 : $1 \mathrm{~cm}$ (gambar 3.) (Tjitrosopomo, 1985;Wilujeng dan Simbiak, 2015). Ujung dan pangkal daun kayu sowang tumpul, dengan tepi daun rata. Terdapat perbedaan warna antara sisi atas dan sisi bawah daun kayu sowang, sisi atas daun kayu sowang tampak lebih hijau, licin atau mengkilat sedangkan sisi bawah daun tampak lebih pucat.

Umumnya masyarakat Kampung Doyo Lama mengenal kayu sowang sejak kayu tersebut masih anakan, dengan melihat dari ciri morfologi batang yang berwarna putih dan bentuk daun yang bulat dan ketika kayu sowang tersebut telah tumbuh menjadi pohon yang dewasa daun akan berwarna kemerah-merahan. Mereka juga berpendapat bahwa kayu sowang hanya dapat tumbuh di daerah-daerah dataran tinggi, tempat-tempat kering, di rumput ila-lang, tumbuh bersama (berasosiasi) Casuarina sp. Kayu sowang yang sudah ditebang dibedakan menjadi tiga bagian yaitu bagian tulang, terdapat tengah berwarna hitam merupakan bagian yang tidak akan lapuk dan tidak dimakan rayap; bagian daging berwarna putih kecoklatan merupakan bagian yang kemudian lapuk dan keropos; bagian kulit pembungkus batang. Masyarakat Doyo Lama biasanya mengambil kayu sowang di gunung Totari, sedangkan mereka menyebut tempat tumbuh kayu sowing Utua.

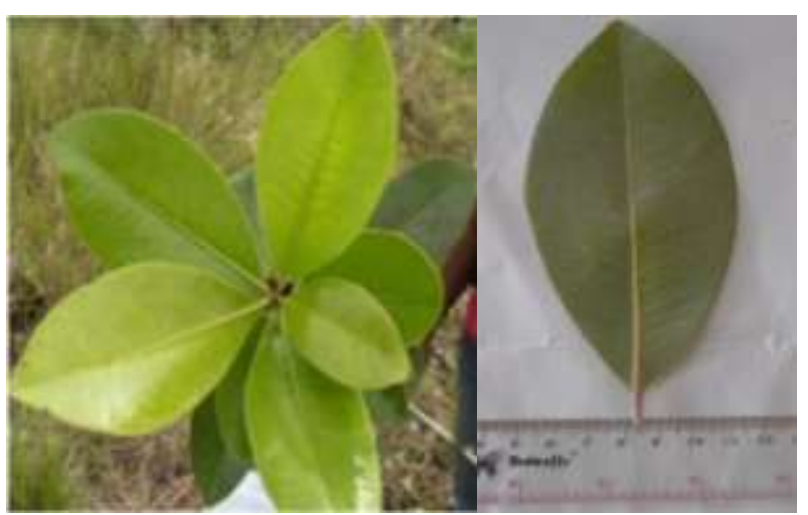

Gambar 1. Daun Kayu Sowang berdaun lebar (Xanthostemon novoguineensis)

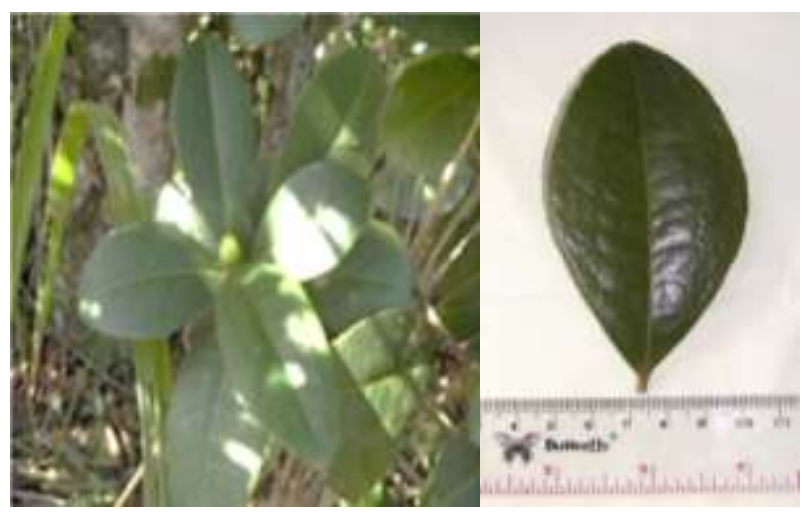

Gambar 2. Daun Kayu Sowang berdaun kecil (Xanthostemon papuanus) 


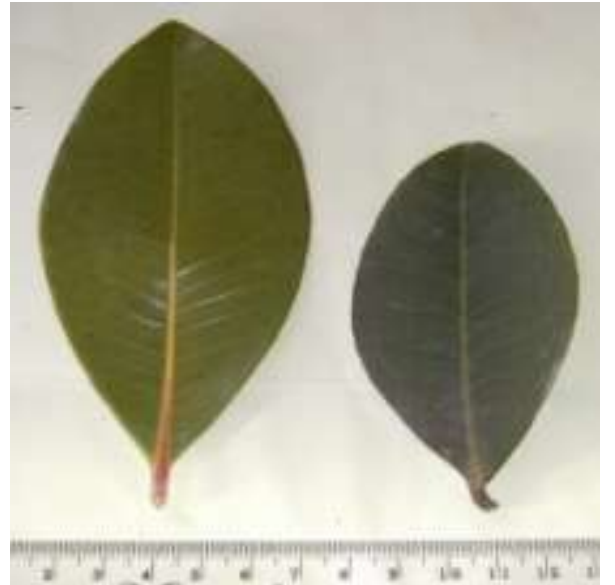

Gambar 3. Perbandingan Ukuran Daun Kayu sowang berdaun lebar dan Kayu sowang berdaun kecil

Menurut hasil wawancara yang dilakukan dengan menggunakan interview guide, pengetahuan tentang kayu sowang di hutan lebih banyak diketahui oleh kaum lelaki (terlebih khusus orang dewasa) karena mereka yang terlibat langsung dalam pengambilannya di hutan dan dalam pengambilan kayu sowang biasanya dilakukan secara beramai-ramai. Kaum wanita hanya bertugas untuk menyiapkan keperluan untuk menunjang aktivitas pengambilan kayu sowang, contohnya memasak dan mengantarkan makanan, sehingga para wanita hanya mengenal kayu sowang setelah diambil dari hutan.

Pengambilan kayu sowang tidak dibatasi usia dan kedudukan sosial. Sekalipun pengambilan kayu sowang dapat dilakukan oleh siapa saja namun harus mendapat ijin dari ondoafi dan kepala suku yang memiliki daerah kekuasaan dimana terdapat populasi kayu sowang. Suku-suku yang menguasai daerah tumbuhnya sowang adalah suku Pangkatana, suku Marweri, dan suku Dike. Ketiga suku ini dikatakan memiliki hubungan tertentu dengan kayu sowang dan tumbuh-tumbuhan lainnya, mereka juga yang mempunyai kemampuan membaca mantra untuk meringankan kayu, serta mengukir pada kayu-kayu yang akan dijadikan tiang raja pada rumah adat. Namun sekarang ini aturan-aturan tentang perijinan dari ondoafi dan kepala suku sebelum mengambil kayu dewasa ini tidak diindahkan lagi karena adanya suku-suku lain yang mendiami daerah-daerah pegunungan dan mengklaim daerah tersebut adalah milik mereka.

Kayu sowang oleh masyarakat Doyo Lama disebut toang, dimanfaatkan sebagai bahan membangun rumah adat, rumah tinggal, ukiran, piring (toje), sendok papeda (hiloi) (gambar 4), penokok sagu, sendok untuk membuat papeda (yangkaru) (gambar 5), tombak (menda), dan anak panah untuk berburu. Pemanfaatan lainnya adalah sebagai bahan bangunan rumah adat, para-para (ake), dan rumah ondoafi. Untuk tiang-tiang utama (tiang raja), dan penggunaan kayu sowang harus tetap utuh dan tidak dibelah sehingga dipilih kayu sowang yang khusus. Pemanfaatannya sebagai bahan ukiran yang melambangkan kebanggaan terlihat dengan 
Jurnal Ilmu Pendidikan Indonesia 9 (2) : 93- 105 | 99

adanya perbedaan ukiran pada masingmasing ondoafi.

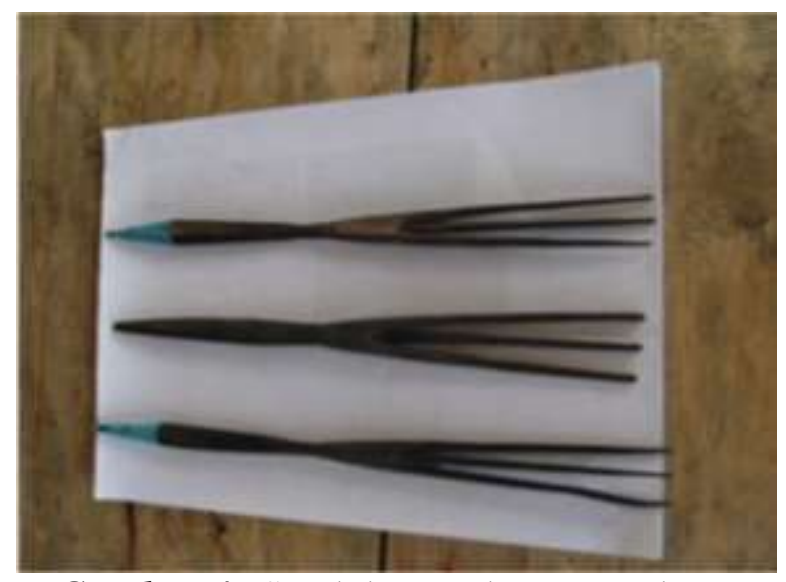

Gambar 4. Sendok papeda yang terbuat dari kayu sowang (hiloi)

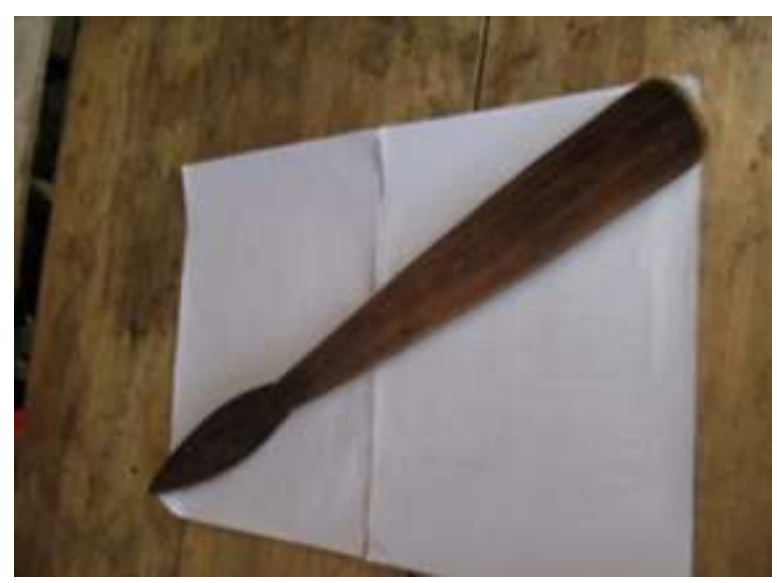

Gambar 5. Sendok untuk membuat papeda yang terbuat dari kayu sowang (yangkaru)

Bagian-bagian lain dari sowang selain kayu, tidak dimanfaatkan seperti daun, bunga, dan biji. Saat ini jumlah pohon kayu sowang di alam sudah sangat terbatas dan bentuk-bentuk pemanfaatannya semakin terbatas karena adanya perubahan pola kehidupan masyarakat dari tradisional menjadi modern.

Pengetahuan dan Pemanfaatan Kayu Sowang oleh Masyarakat Kampung Harapan
Masyarakat Kampung Harapan mengenal dua spesies kayu sowang, mereka menggunakan petunjuk morfologi yang berbeda dengan masyarakat Kampung Doyo Lama, yang dibedakan berdasarkan morfologi bunga atau warna bunga kayu sowang, yaitu spesies yang pertama adalah kayu sowang yang memiliki bunga berwarna merah dan yang kedua spesies kayu sowang yang memiliki bunga berwarna kuning. Mereka beranggapan kayu sowang yang memiliki bunga berwarna merah lebih kuat dari yang memiliki bunga berwarna kuning. Bunga kayu sowang merupakan bunga majemuk terbatas, bunga kayu sowang berwarna merah memiliki rumus bunga K5C5A G1, yang berarti kelopak (calix) berjumlah lima dan berwarna merah, dengan mahkota (corolla) berjumlah lima, dengan benang sari (androecium) tak terhingga dan putik (gynaecium) satu (gambar 6). Hal yang sama dari penelitian Wilujeng dan Simbiak (2015), sebagaimana bunga Myrtaceae pada umumnya, daun mahkotanya berukuran kecil tetapi bunga memiliki tangkai sari yang panjang, rapat, dan banyak sehingga tampak menyolok. Bunga sowang berwarna merah dan tersusun dalam perbungaan majemuk berbentuk malai rata yang bersifat aksilar. Perbungaan sowang disusun oleh 3-10 unit perbungaan yang tersusun rapat dan umumnya masing-masing unit perbungaan 
terdiri atas 3 bunga, sering dijumpai dapat berjumlah 2 atau 4. Sedangkan bunga kayu sowang berwarna kuning mempunyai rumus bunga $\mathrm{K} 5 \mathrm{C} 4 \mathrm{~A} \sim \mathrm{G} 1$, yang berarti kelopak (calix) berjumlah lima dan berwarna hijau, dengan mahkota (corolla) berjumlah empat sampai lima, berwarna putih, dengan benang sari tak terhingga dengan kepala sari berwarna kuning dan satu putik. Menurut masyarakat bunga kayu sowang berwarna kuning karena dilihat dari warna kepala sari (anther) yang berwarna kuning (gambar 7).

Sama halnya dengan masyarakat Kampung Doyo Lama, masyarakat Kampung Harapan mengenal kayu sowang mulai dari anakan hingga tumbuhan dewasa dengan melihat morfologinya seperti batang yang berwarna coklat keputih-putihan, permukaan batang yang agak terkelupas, bentuk daun yang tebal, bunga yang mirip dengan bunga jambu, dan bila kulit bagian dalam batangnya dikupas akan memperlihatkan warna kemerah-merahan seperti pada kulit matoa.

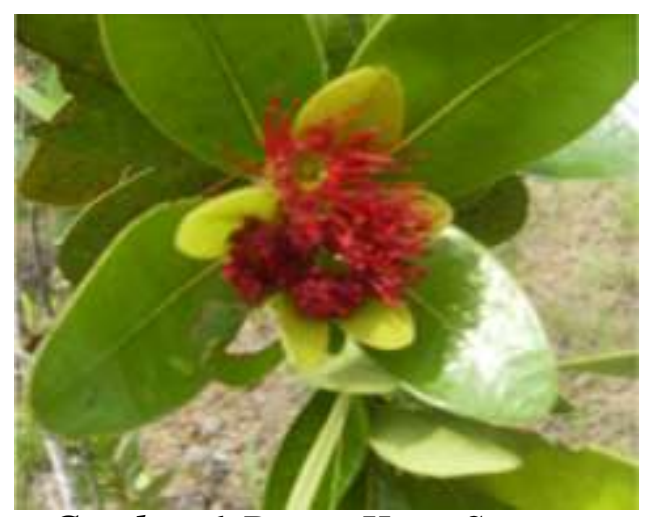

Gambar 6. Bunga Kayu Sowang berbunga merah (Xanthostemon novoguineensis)

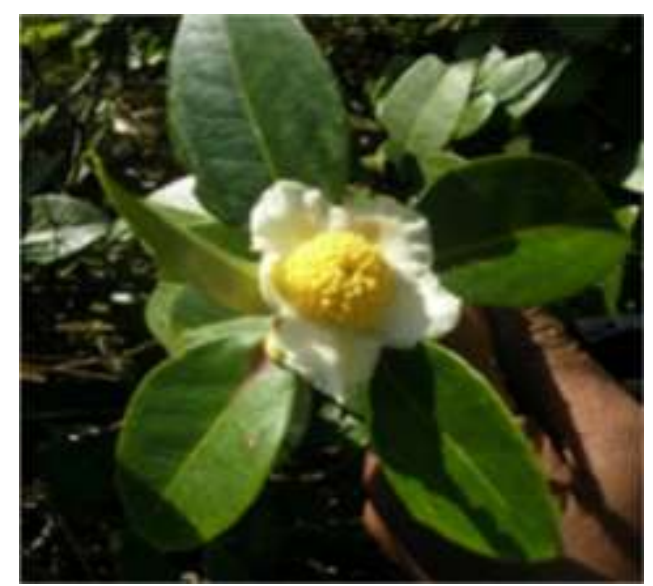

Gambar 7.Bunga Kayu Sowang berbunga kuning (Xanthostemon papuanus)

Masyarakat Kampung Harapan sejak dulu mengenal dan memanfaatkan kayu sowang. Mereka menyebut kayu sowang dengan nama "Howan" yang berarti kayu yang tahan lama (tidak mudah lapuk). Menurut pengetahuan mereka kayu sowang tersebar luas mulai dari Ifar Gunung sampai dengan Pasir Dua dan tumbuh pada daerahdaerah yang kering/tandus, biasanya tumbuh bersama alang-alang, cemara dan palempaleman. Terdapat 3 sistem pembagian kawasan antara lain; kawasan khusus (Hoangla) merupakan kawasan yang diperuntukan sebagai tempat pengambilan bahan pembuatan rumah, tidak boleh diganggu dan tidak boleh berkebun; Kawasan berkebun (Ongqla) kawasan untuk berkebun; Hutan Sagu (Fiqla) kawasan yang terdiri dari komunitas tumbuhan sagu atau dusun sagu.

Masyarakat Kampung Harapan memanfaatkan kayu sowang untuk berbagai 
keperluan antara lain: untuk membuat rumah (sebagai tiang rumah) (Gambar 8, 9), untuk membelah sagu, alat bercocok tanam (tugal), untuk membuat alat rumah tangga (seperti sendok papeda atau iloi). Penggolongan kayu untuk pembuatan rumah dibedakan menjadi tiga yaitu pendek (klehu) untuk tiang-tiang pancang dengan ukuran 4-6 m, sedang (vinyam) untuk rimbalak dengan ukuran $8 \mathrm{~m}$, dan panjang (hotehu) untuk tiang raja dan bumbungan rumah dengan ukuran $12 \mathrm{~m}$.

Pengambilan kayu sowang untuk berbagai keperluan mempunyai aturanaturan yang harus dipatuhi oleh semua orang. Pada Masyarakat Kampung Harapan, marga Puraro memiliki hak atau kuasa terhadap kayu sowang sehingga pihak manapun yang ingin mengambil kayu sowang harus mendapatkan izin dari marga ini dan ondoafi. Pengambilan kayu sowang untuk keperluan adat seperti membangun rumah atau sebagai alat tukar pada acara perkawinan adat, biasanya telah dihitung berapa banyak yang akan diperlukan. Setelah diberitahukan banyaknya kayu yang diperlukan dan diberi izin mengambil maka sejumlah kaum lelaki akan pergi mencari kayu sowang dengan cara menyebar ke beberapa tempat dan kayu-kayu yang diperoleh akan dibawa secara bersama-sama.

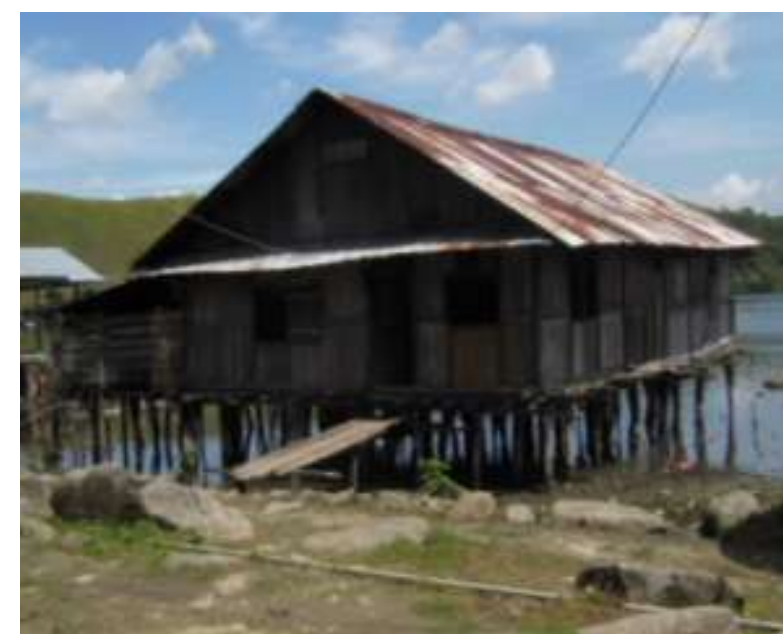

Gambar 8. Rumah yang menggunakan kayu sowang.

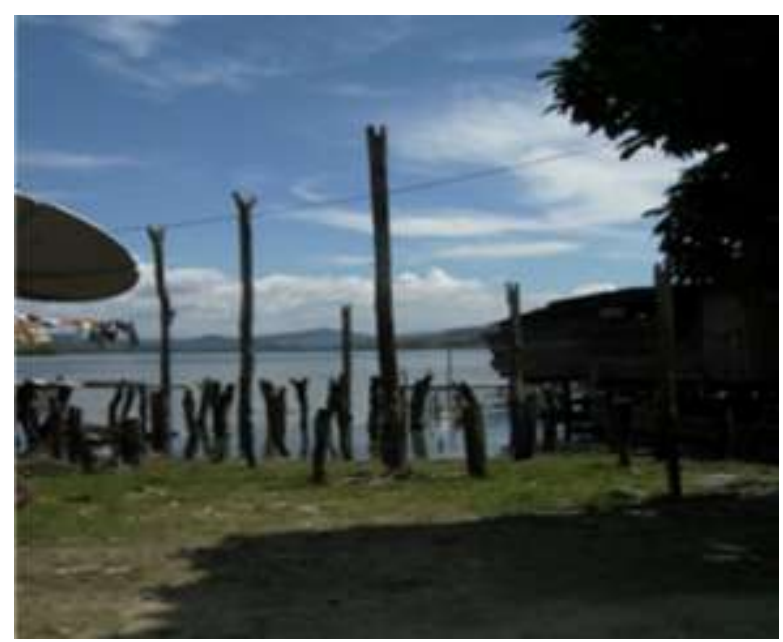

Gambar 9. Bekas Tiang Rumah dari kayu sowang yang masih bertahan hingga sekarang.

Tempat tumbuh kayu sowang dalam masyarakat Kampung Harapan disebut hoangqla. Ukuran kayu sowang yang dapat ditebang adalah batang pohon telah mencapai ukuran lengan atau betis atau paha orang dewasa. setelah diukur dan dibandingkan dengan ukuran diameter yang sebenarnya pada tiang rumah dari kayu sowang maka kisarannya antara 19,5-25cm, untuk ukuran paha orang dewasa, dan diamater $12-15,5 \mathrm{~cm}$ untuk ukuran betis 
orang dewasa. Pada waktu lampau untuk menebang kayu sowang mereka melakukannya dengan cara membakar bagian pangkal pohon, namun pada masa kini dengan menggunakan mesin gergaji (chain-saw). Waktu yang diperlukan untuk mencari dan membawa kayu Sowang dapat mencapai dua hari. Setelah semua kayu diperoleh maka akan dibawa secara bersama-sama ke kampung. Kayu sowang merupakan jenis kayu yang sangat keras dan berat sehingga dalam mengangkutnya masyarakat sering menggunakan bantuan magic. Suku Puraro yang merupakan suku pemilik kayu adalah yang berhak menggunakan magic dengan cara menepuknepuk kayu sowang sehingga akan terasa ringan dan dapat diangkat oleh 4 laki-laki dewasa. Bila tanpa kekuatan supranatural biasanya sebuah kayu sowang diangkat oleh 10 hingga 20 orang laki-laki, tergantung besar kecilnya kayu.

\section{Perbandingan Pengetahuan dan Upaya Konservasi Kayu Sowang menurut Masyarakat Kampung Doyo lama dan Masyarakat Kampung Harapan.}

Tabel 1. Rumusan perbandingan pengetahuan dan upaya konservasi kayu sowang di Kampung Doyo Lama dan Kampung Harapan.

\begin{tabular}{|c|c|c|c|}
\hline No & $\begin{array}{c}\text { Indikator utama } \\
\text { sebagai } \\
\text { perbandingan }\end{array}$ & $\begin{array}{c}\text { Masyarakat } \\
\text { Kampung Doyo Lama }\end{array}$ & $\begin{array}{c}\text { Masyarakat } \\
\text { Kampung Harapan }\end{array}$ \\
\hline 1 & $\begin{array}{l}\text { Petunjuk morfologi } \\
\text { dalam } \\
\text { mengidentifikasi } \\
\text { kayu sowang }\end{array}$ & $\begin{array}{l}\text { Menggunakan morfologi daun yaitu } \\
\text { spesies yang berdaun lebar dan } \\
\text { spesies yang berdaun kecil }\end{array}$ & $\begin{array}{l}\text { Menggunakan warna bunga, yaitu } \\
\text { spesies yang berbunga merah dan } \\
\text { spesies yang berbunga kuning. }\end{array}$ \\
\hline 2 & $\begin{array}{l}\text { Pengetahuan dan } \\
\text { pemberian nama } \\
\text { kayu sowang }\end{array}$ & $\begin{array}{l}\text { 1. Pengetahuan tentang } \\
\text { manfaat,ekologi dan morfologi, } \\
\text { telah diperoleh sejak lama dan } \\
\text { diwariskan dari generasi ke } \\
\text { generasi } \\
\\
\text { 2. Kayu sowang disebut Toang atau } \\
\text { kayu yang keras dan kuat }\end{array}$ & $\begin{array}{l}\text { 1.Pengetahuan tentang manfaat, } \\
\text { ekologi dan morfologi, telah } \\
\text { diperoleh sejak lama dan diwariskan } \\
\text { dari generasi ke generasi } \\
\text { 2.Kayu sowang disebut Howan, atau } \\
\text { kayu yang tahan lama dan tidak } \\
\text { mudah lapuk }\end{array}$ \\
\hline 3 & $\begin{array}{c}\text { Pengetahuan tentang } \\
\text { pemanfaatan kayu } \\
\text { sowang hubungan } \\
\text { dengan gendernya }\end{array}$ & $\begin{array}{l}\text { 1. Kaum laki-laki lebih baik } \\
\text { pengetahuannya karena laki-laki } \\
\text { senantiasa terlibat dalam } \\
\text { keseluruhan kegiatan yang } \\
\text { berkaitan dengan kayu sowang. } \\
\\
\text { 2. Kaum muda cedererung tidak } \\
\text { memiliki pengetahuan yang baik } \\
\text { terhadap kayu sowang. }\end{array}$ & $\begin{array}{l}\text { 1. Kaum laki-laki lebih baik } \\
\text { pengetahuannya karena laki-laki } \\
\text { senantiasa terlibat dalam } \\
\text { keseluruhan kegiatan yang berkaitan } \\
\text { dengan kayu sowang. } \\
\\
\text { 2.Kaum muda cedererung tidak } \\
\text { memiliki pengetahuan yang baik } \\
\text { terhadap kayu sowang }\end{array}$ \\
\hline 4 & $\begin{array}{c}\text { Suku yang mengusai } \\
\text { tempat tumbuh dan } \\
\text { mantra kayu sowang }\end{array}$ & $\begin{array}{l}\text { Ada tiga suku, yaitu Pangkatana, } \\
\text { Mareweri, dan Dike }\end{array}$ & Hanya ada satu suku yaitu, Puraro \\
\hline
\end{tabular}




\begin{tabular}{|c|c|c|c|}
\hline No & $\begin{array}{c}\text { Indikator utama } \\
\text { sebagai } \\
\text { perbandingan } \\
\end{array}$ & $\begin{array}{c}\text { Masyarakat } \\
\text { Kampung Doyo Lama }\end{array}$ & $\begin{array}{c}\text { Masyarakat } \\
\text { Kampung Harapan }\end{array}$ \\
\hline 5 & Bentuk Pemanfaatan & $\begin{array}{l}\text { 1. Bahan untuk membangun rumah } \\
\text { adat, rumat tinggal, ukiran, } \\
\text { perlengkapan makan, penokok } \\
\text { sagu, tombak dan anak panah. } \\
\text { 2. Bentuk pemanfaatan kayu sowang } \\
\text { telah atau cenderung terabaikan } \\
\text { karena adanya kemajuan IPTEK } \\
\text { dan perkembangan kehidupan } \\
\text { modern. }\end{array}$ & $\begin{array}{l}\text { 1. Bahan untuk membangun rumah } \\
\text { adat, rumat tinggal, ukiran, } \\
\text { perlengkapan makan, penokok sagu, } \\
\text { tombak dan anak panah } \\
\text { 2. Bentuk pemanfaatan kayu sowang } \\
\text { telah atau cenderung terabaikan } \\
\text { karena adanya kemajuan IPTEK dan } \\
\text { perkembangan kehidupan modern }\end{array}$ \\
\hline 6 & $\begin{array}{c}\text { Konservasi kayu } \\
\text { sowang }\end{array}$ & $\begin{array}{l}\text { Belum ada kegiatan konservasi } \\
\text { terhadap kayu sowang, hanya } \\
\text { dibiarkan tumbuh secara alami. }\end{array}$ & $\begin{array}{l}\text { Belum ada kegiatan konservasi } \\
\text { terhadap kayu sowang, hanya } \\
\text { dibiarkan tumbuh secara alami }\end{array}$ \\
\hline
\end{tabular}

Upaya Konservasi Kayu Sowang oleh Masayakat Kampung Doyo Lama dan Kampung Harapan

Pengetahuan tentang kayu sowang dewasa ini hanya diperkenalkan oleh para orang tua kepada generasi muda melalui penuturan cerita. Pemanfaatan kayu sowang untuk keperluan kehidupan sosial dan budaya masyarakat sudah berkurang karena keberadaannya yang sulit diperoleh, dan sebagai gantinya mereka lebih memanfaatkan kayu besi dan produk-produk pabrik lainnya. Masyarakat Kampung Doyo Lama dan Kampung Harapan tidak mengetahui lamanya waktu pertumbuhan kayu sowang. Mereka hanya mengetahui bahwa pertumbuhannya sangat lambat sesuai dengan pemanfaatannya yang sangat lama. Mereka juga tidak melakukan upaya untuk melindungi dan memperbanyak, tetapi hanya dibiarkan tumbuh secara alami dihabitatnya. Mereka berpendapat perkembangbiakan kayu sowang di alam terjadi dengan bantuan burung yang membawa atau menjatuhkan biji sowang dan melalui aliran air ketika banjir.

Setelah ditelusuri dan telaah maka pengetahuan tentang penyebaran kayu sowang dengan bantuan burung agak sulit untuk diterima, karena berdasarkan hasil penelitian lainnya tentang ekologi kayu sowang ternyata hanya jenis-jenis serangga tertentu saja yang beraosiasi dengan sowang. Faktor cara perkembangbiakan kayu sowang yang terbatas dan pertumbuhan yang lambat, tanpa bantuan dari hewan lainnya dapat pula memberikan pengaruh terhadap penurunan populasinya.

Faktor-faktor lainnya yang berpengaruh yaitu adanya perpindahan penduduk dari Kabupaten Jayawijaya yang bermukim dan berkebun di sekitar kawasan cagar alam Pegunungan Cycloop, dimana habitat kayu sowang dirubah menjadi tempat pemukiman dan lahan perkebunan (Tanjung, dkk. 2008). 
Masih ditemukan kegiatan ekspoitasi kayu sowang oleh suku lain yang bukan berasal dari Doyo Lama dan kampung Harapan. Tujuan eksploitasi tersebut untuk menjadikan kayu sowang sebagai bahan pembuatan arang dan bahan bangunan. Faktor-faktor tersebut memberikan pengaruh yang nyata terhadap penurunan populasi kayu sowang di kawasan cagar alam Pegunungan Cycloop. Walaupun penduduk kampung Doyo Lama dan kampung Harapan sudah jarang bahkan tidak lagi menggunkan dan memanfaatkan kayu sowang.

\section{SIMPULAN DAN SARAN}

\section{SIMPULAN}

Pengetahuan dan pemanfaatan kayu sowang secara tradisional oleh masyarakat Kampung Doyo Lama dan Harapan semakin berkurang, dipengaruhi oleh perkembangan kehidupan modern. Sampai saat ini belum ada upaya dan kegiatan konservasi terhadap kayu sowang dikedua kampung tersebut.

\section{SARAN}

Perlu adanya tindakan pelestarian tentang pengetahuan, pemanfaatan, dan nilai sosial budaya kayu sowang kepada masyarakat Kampung Doyo Lama dan Kampung Harapan teristimewa kepada generasi mudanya.

\section{UCAPAN TERIMA KASIH}

Ucapan terima kasih terima ditujukan kepada Masyarakat dan Kepala Kampung Doyo Lama dan Kampung Harapan atas ijin terlaksananya penelitian ini. Terima kasih juga peneliti sampaikan kepada semua pihak yang telah membantu pelaksanaan penelitian ini.

\section{DAFTAR PUSTAKA}

Cannon J. C. 2020. Studi: Papua, Pulau dengan spesies Tumbuhan Paling Banyak di Dunia.Septeber 10, 2020. https://www.mongabay.co.id/2020/ 09/10/studi-papua-pulau-denganragam-hayati-tumbuhan-palingtinggi-di-dunia/;

Samedi, 2015. Konservasi Keanekaragaman Hayati Indonesia: Rekomendasi Perbaikan Undang-Undang Konservasi. Jurnal Hukum Lingkungan Vol.2 (2), 1-28;

Jamlean, V. M. 1998. Identifikasi dan Pemanfaatan Kayu Sowang (Xanthostemon spp) Pada Masyarakat Asli Sentani dan Masyarakat Pendatang di Kabupaten DATI II Jayapura. Skripsi Sarjana Kehutanan FAPERTA Universitas Cenderawasih Manokwari;

Tanjung R.H., Lunga, N., Kalor, J. 2008. Eksplorasi dan Etnobotani kayu sowang (Xanthostemon sp.) pada Masyarakat di sekitar CA.Cycloops. Laporang Hasil Penelitian Research Grant IM-HERE. Jurusan Biologi FMIPA UNCEN; 
Jurnal Ilmu Pendidikan Indonesia 9 (2) : 93- 105 | 105

Tjitrosopomo G. 1985. Morfologi

WWF. 1991. Cagar Alam Pegunungan

Tumbuhan. Gadjah Mada

University Press. Yogyakarta; Cycloop/Dafonsoro dan Permasalahannya. WWF. Jayapura.

Wilujeng, S., dan Simbiak, M. (2015). Karakteristik Morfologi

XanthostemonnovaeguineensisValet on (Myrtaceae) dari Papua. In Prosiding Seminar Nasional Masyarakat Biodiversity Indonesia (pp. 466-471). Bandung, Indonesia: Masyarakat Biodiversity Indonesia; 